\title{
ELECTROLYTE SOLUTION EFFECT ON THE PHYSICAL PROPERTIES OF ELECTRICAL INSULATOR BODY FORMED USING LOCAL IRAQI MATERIAL
}

\author{
*Fadhil A. Resan, ** Azhar J. Dawod and ***Itab F. Hussein \\ *Assistant Professor, Babylon University, College of Science, E-mail: fadhil_rasin @yahoo.com \\ ** Lecturer, Department of Physics, College of Science, Al-Nahrain University. \\ ***Assistant Lecturer, Department of Physics, College of Science, Al - Mustansryiah University, \\ E-mail: itab itabfadhil@yahoo.Co-in
}

\section{Abstract}

Ceramic Electrical Insulator body was prepared using Iraqi local materials. These are kaolin Duakhla, Arudhuma Sand glass and potash feldspar with weight percentage (45\%, $25 \%, 30 \%$ )respectively, of controlled particle size distribution. Chemical and Heat treatment was performed on kaolin duakhla, Arudhuma Sand glass as a first step. Followed by milling, classification, mixing, forming and firing, through the process of mixing electrolyte solution and mineralizer were added at different concentration for electrolyte solution, $(1 \%, 0.7 \%, 0.5 \%$, $0.2 \%$, and $0.1 \%$ ). The electrolyte solution was prepared by mixing sodium carbonate and sodium silicate by (2:1) ratio, while the mineralizer, Zinc Oxide, was added at fixed weight percentage. The measurements were under taken on disk sample burnt at firing temperatures of $(1250,1300,1350){ }^{\circ} \mathrm{C}$.

The Conclusion behind these study were the optimum properties obtained, by adding $2 \%$ weigh percentage of zinc oxide, and using (0.2 - 0.5)electrolyte solution concentration, gives good mechanical, thermal and dielectric properties. These results related in some what, to the cation exchange property of local clay which controls the surface charge of clay.

Keyword: Electrical insulator, Electrolyte solution, Physical properties

\section{Introduction}

Ceramic insulators (more commonly, porcelain insulator) occupy vital area of these fields; porcelain is the material which was made of mixture of various white burning clays and fluxes of such nature and in such properties as will produce a dense and vitrous body [1]. Electrical porcelains: are chiefly used in insulators and other parts of the electrical applications at ultra high frequencies to specialized problems of direct current; from low to high voltage $[1,2]$. This study, concern with the effect of electrolyte solution on dielectric, mechanical and thermal properties for porcelain body prepared from local materials.

\section{Theoretical Part}

Electrolytes, dissolved and particulate organic matter, and inorganic particulates, comprised of clays, quartz, carbonates, and a variety of metal oxides [3]. Thermal movement and Colloidal particles when suspended in water are charged and are surrounded by a water shell. The molecules of water within this shell are rigidly held by particle and have a different character and properties from those in the remainder of the dispersion medium [1].

When a charged colloidal particle is immersed in an electrolyte solution, it is surrounded by counterions-i.e.; small ions of opposite sign-to balance the surface charge. The charged colloidal surface along with the neutralizing diffuse layer of counterions is often referred to as the electric double layer EDL, which plays an important role in many aspects of interfacial phenomena [4]. Clay minerals have the property of sorting certain anions and cations, retaining these in an exchangeable state; i.e. they are exchangeable for other anions or cations by treatment with such ions in a water solution (the exchange reaction also take place sometimes in anon aqueous environment). The exchangeable ions are held around the outside of silicaalumina clay mineral structural units, and the exchange reaction generally does not affect the structure of silica-alumina clay 
packet. In clay minerals the common exchangeable cations are calcium, magnesium, hydrogen, potassium, and sodium, frequently in about that order of general relative abundance [5]. The major properties for ceramic insulator are dielectric, mechanical and thermal characteristics. The dielectric properties are dielectric constant and dielectric loss index. The dielectric constant represent of the ability of material for store as charge relative to vacuum and is a characteristic material property $[6,7,8]$, is given in the relation

$$
\varepsilon^{\prime}=\left(1 / \varepsilon_{\circ}\right)[(d a / A) C]
$$

where $\varepsilon$ is the relative dielectric constant, $\varepsilon_{o}$ is the dielectric constant of vacuum, da is parallel plate capacitor distance, $\mathrm{A}$ is a cross section area, and $\mathrm{C}$ is capacitance of capacitor in medium. The dielectric loss index is defined as the magnitude of imaginary part of relative complex permittivity $[\mathbf{9 , 1 0}]$.

$$
K^{\prime \prime}=\left[\left(1 / R_{p} \omega \varepsilon_{\circ}\right) d_{s} / A\right]
$$

where $R_{p}$ is the measured value for the material resistance [7].

Thermal conduction is the phenomenon by which heat is transported from high-to low temperature regions of substance. Which are measured by using less disc technique [11] the mechanical behavior of materials described by their mechanical properties; these tests are designed to represent different type of loading condition [12].

If a force, $\mathrm{F}$, applied to the cross section area of a bar A, one obtain normalized term called the stress, thus [13]

$$
\sigma(M P a)=\frac{F}{A_{\circ}}
$$

where

$\sigma$ is Compression strength in (MPa).

$A_{\circ}$ is the original cross-section of the sample in $\left(\mathrm{m}^{2}\right)$.

$\mathrm{F}$ is the normal force in $(\mathrm{N})$.

\section{Experimental Part}

The samples were prepared in a process as defined in table (2) where the material and their chemical composition are defined in table (1). $2 \%$ wt of Zinc Oxide was added to the mixture followed by mixing for 2 hours. The final mixture then divided into seven groups related to different percentage of electrolyte solution which is added as given in table (2). A polyvinyl alcohol binder was prepared and applied with $1 \%$ wt for each group. The mixing process was done under heating $\left(80^{\circ} \mathrm{C}\right)$ until it get a slurry form, and then dried at $70^{\circ} \mathrm{C}$ with continuous mixing for 3 hours, until obtaining agglomerated powders. The final powder was milled for about one hour, and then sieved using a sieve of size $250 \mu \mathrm{m}$. The sieved powders then pressed by using press (model (38888.4D10A00, made in USA)), with pressure $7 \mathrm{MPa}$, a disc form of diameter $30 \mathrm{~mm}$ and $3 \mathrm{~mm}$ thickness. These samples were dried in a furnace at a temperature $70{ }^{\circ} \mathrm{C}$ for two hours. The prepared samples burnt by a furnace (model (Hi 62, Ti7, 1700, Nabertherm)) using different temperatures 1250, 1300, and 1350 ${ }^{\circ} \mathrm{C}$, with sintering time $2 \mathrm{hr}$. and sintering rate $100{ }^{\circ} \mathrm{C} / \mathrm{hr}$. Electrolyte solution are prepared using $\mathrm{Na}_{2} \mathrm{CO}_{3} \& \mathrm{Na}_{2} \mathrm{SiO}_{3}$ by ratio $2: 1$ respectively, from this mixture, we determine the amount of adding distilled water to obtain electrolyte

Solution with concentration $5 \%$. So the amount of distill water added was 114 ml. Mixing 4 gram of $\mathrm{Na}_{2} \mathrm{CO}_{3}$ with 2 gram of $\mathrm{Na}_{2} \mathrm{SiO}_{3}$ and solving these massed in 50 $\mathrm{ml}$ distilled water, with continues mixing process for half hour using magnetic stirrer (model (Great Britain, serial 11750)). After that we carried on adding distilled water to obtain a final volume $114 \mathrm{ml}$. The preparation of electrolyte solutions with the concentrations $(1 \%, 0.7 \%, 0.5 \%, 0.2 \%$, and $0.1 \%$ ) from mentioned above $5 \%$ done by using dilution equation given by: [14].

$$
\mathrm{M}_{\mathrm{i}} \mathrm{V}_{\mathrm{i}}=\mathrm{M}_{\mathrm{j}} \mathrm{V}_{\mathrm{J}}
$$

where $M_{i}$ is the percentage of solution before dilution, $\mathrm{V}_{\mathrm{i}}$ is the volume of solution before dilution, $\mathrm{M}_{\mathrm{j}}$ is the percentage of solution after dilution, $\mathrm{V}_{\mathrm{j}}$ is the volume of solution after dilution. Table (1) shows the chemical composition of the raw material 
Table (1)

Chemical composition for raw materials

\begin{tabular}{||c||c||c||c|}
\hline Material & $\begin{array}{c}\text { Kaolin } \\
\text { Duekhla }\end{array}$ & $\begin{array}{c}\text { Ardhuma } \\
\text { sandglass }\end{array}$ & $\begin{array}{c}\text { potash } \\
\text { feldspar }\end{array}$ \\
\hline \hline oxide & percentage & percentage & percentage \\
\hline \hline $\mathrm{SiO}_{2}$ & 52.35 & 97.39 & 69.61 \\
\hline $\mathrm{Fe}_{2} \mathrm{O}_{3}$ & 1.31 & 0.08 & 0.19 \\
\hline $\mathrm{Al}_{2} \mathrm{O}_{3}$ & 34.02 & 0.38 & 15.07 \\
\hline \hline $\mathrm{TiO}_{2}$ & 0.12 & - & - \\
\hline \hline $\mathrm{CaO}$ & 1.2 & 0.246 & 0.98 \\
\hline \hline $\mathrm{MgO}$ & 1.11 & 0.015 & 0.13 \\
\hline \hline $\mathrm{SO}_{3}$ & 0.45 & - & - \\
\hline \hline $\mathrm{Na}_{2} \mathrm{O}$ & - & 0.18 & 3.25 \\
\hline \hline $\mathrm{K}_{2} \mathrm{O}$ & - & 0.03 & 8.35 \\
\hline
\end{tabular}

\section{Result and Discussion}

The change of the dielectric properties, thermal conductivity, and compression strength with concentration of electrolyte solution are shown in figures $(1,2$, and 3$)$ respectively.

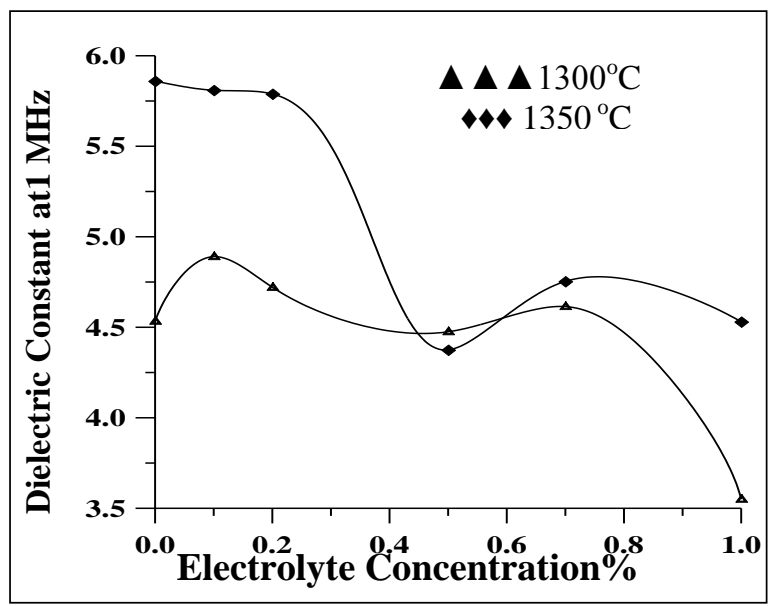

Figure(1). The change of dielectric constant with concentration of electrolyte solution.

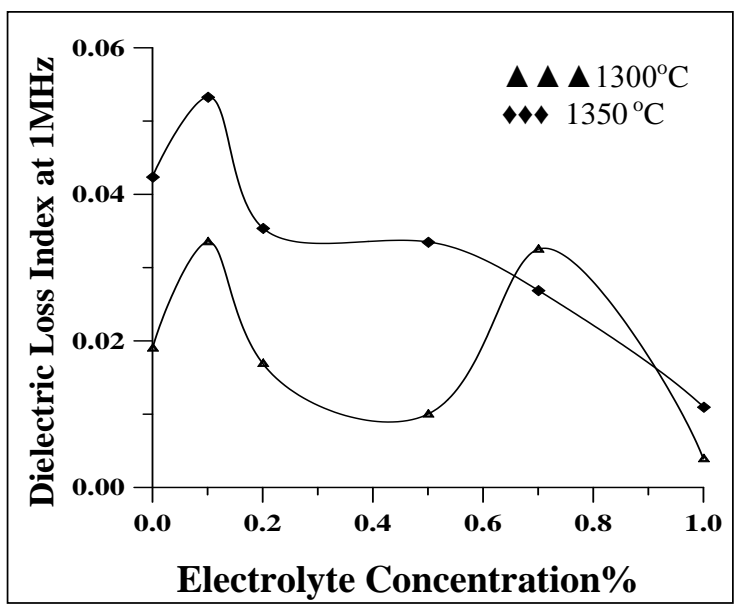

Figure (2). The change of dielectric loss index with concentration of electrolyte solution

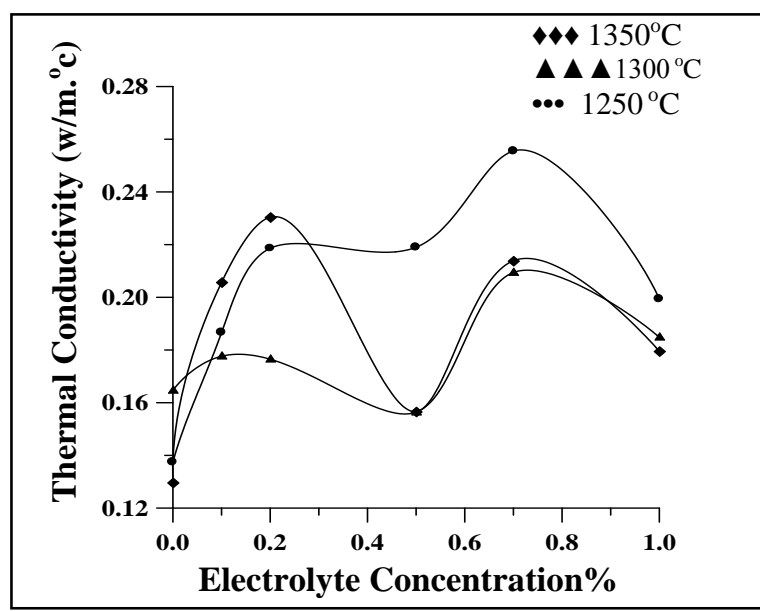

Figure (3). The thermal conductivity of the samples with different concentration of electrolyte solution as a function of sintering temperatures.

As a practical conclusion, one can plot the value of dielectric constant and dielectric loss index (measured at $1 \mathrm{MHz}$ ), as a function of concentration of electrolyte solution, for samples firing at $1300{ }^{\circ} \mathrm{C}$ and $1350{ }^{\circ} \mathrm{C}$, as shown in figures (1) and (2). The behavior clearly shows that there are a highly variation and non- linear phenomena. This can be explain, because of each group having the same percentage of the raw material (kaolin Duekhla, Aruthma Sand Glass and feldspar) impling to the ability of the results depending mechanism of reaction

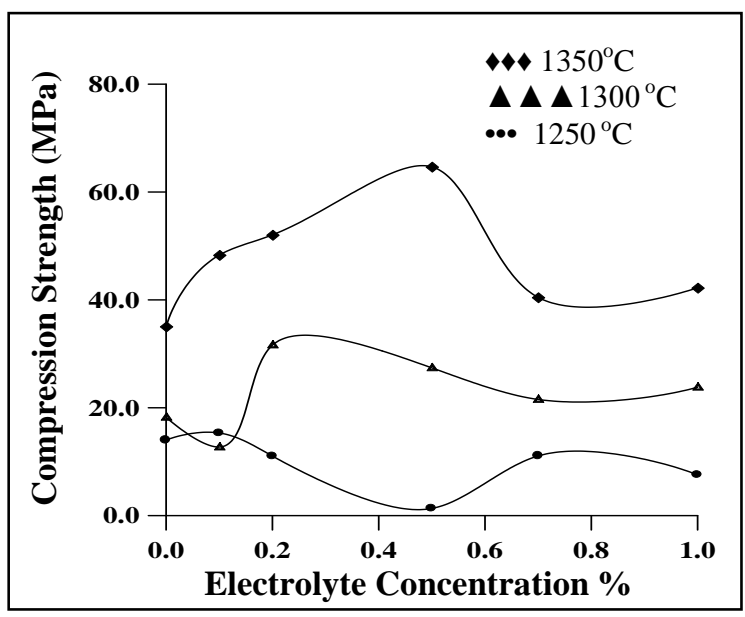

Figure(4). The Compressive Strength for different concentration of electrolyte solution as a function of sintering temperatures. 
Table (2).

Chemical composition of each group.

\begin{tabular}{|c|c|c|c|c|c|c|c|}
\hline \multirow{2}{*}{ Oxides } & \multicolumn{7}{|c|}{ Group No. } \\
\hline & $\mathbf{M}$ & M1 & M2 & M3 & M4 & M5 & M6 \\
\hline $\mathrm{SiO}_{2}$ & 68.78 & 68.78 & 69.78 & 69.4 & 69.2 & 68.9 & 68.8 \\
\hline $\mathrm{Fe}_{2} \mathrm{O}_{3}$ & 0.65 & 0.65 & 0.65 & 0.65 & 0.65 & 0.65 & 0.65 \\
\hline $\mathrm{Al}_{2} \mathrm{O}_{3}$ & 19.93 & 19.93 & 19.93 & 19.93 & 19.93 & 19.93 & 19.93 \\
\hline $\mathrm{TiO}_{2}$ & 0.05 & 0.05 & 0.05 & 0.05 & 0.05 & 0.05 & 0.05 \\
\hline $\mathrm{CaO}$ & 0.91 & 0.91 & 0.91 & 0.91 & 0.91 & 0.91 & 0.91 \\
\hline MgO & 0.54 & 0.54 & 0.54 & 0.54 & 0.54 & 0.54 & 0.54 \\
\hline $\mathrm{SO}_{3}$ & 0.2 & 0.2 & 0.2 & 0.2 & 0.2 & 0.2 & 0.2 \\
\hline $\mathrm{Na}_{2} \mathrm{O}$ & 1.02 & 1.02 & 2.02 & 1.72 & 1.52 & 1.22 & 1.12 \\
\hline $\mathbf{K}_{2} \mathbf{O}$ & 2.5 & 2.5 & 2.5 & 2.5 & 2.5 & 2.5 & 2.5 \\
\hline $\mathrm{LO}_{\mathbf{I}}$ & 5.86 & 5.86 & 5.86 & 5.86 & 5.86 & 5.86 & 5.86 \\
\hline
\end{tabular}

between $\mathrm{SiO}_{2}-\mathrm{Na}_{2} \mathrm{O}$, and by the comparison with the percentage contribution in the each group (i.e. $\mathrm{Al}_{2} \mathrm{O}_{3} \%, \mathrm{SiO}_{2} \%, \mathrm{TiO}_{2} \%, \mathrm{MgO} \%$, $\mathrm{Na}_{2} \mathrm{O} \%, \mathrm{~K}_{2} \mathrm{O} \%, \mathrm{CaO} \%$ etc.), which may defined in table (2).

Now, we can say the above reaction have a great effect by the change of the properties with concentration of electrolyte solution as figures (3) and (4). Thermal conductivity of porcelain consider low, but the thermal conductivity of $\mathrm{Al}_{2} \mathrm{O}_{3}$ is consider high at $\left(100{ }^{\circ} \mathrm{C}\right)$. On the practical approach one can show that the behavior of thermal conductivity as a function to the concentration of electrolyte solution is non linear, but have the similar behavior of change with the concentration increases, this because of the effect of many parameters come from structural formation through heat treatment under the effect of electrolyte solution. The effect can not be studied in this investigation because it needs the advanced techniques and analysis which regarded as a study for future work (i.e. phase change, porosity, thermal conductivity at high temperatures.). It should be noticed that the thermal conductivity increase with the decrease of percentage of electrolyte concentration, and the samples that sintered at high temperature $\left(1350^{\circ} \mathrm{C}\right)$ show high value of thermal conductivity. The best selected regions of thermal conductivity are in the range $0.2-0.5 \%$ concentration of electrolyte solution.

When each particle is completely surrounded by a film of water of the required thickness, the additional of further water will effect a reduction in the strength of the fired articles due to mainly to the increase in porosity which results. So the requirement is to add bonding agent, which may seriously affect the strength of the penetrated material. This bonding agent is electrolytes, when added to clay in form of pastes and slips, considerably increase the strength. The mechanism, by which the strength of materials is increased by the addition of electrolyte, is probably intimately linked to the deflocculating effects. The particles are more readily dispersed in water when electrolyte are present and a better distribution of plastic material is there by achieved. The limit of adding bounding agent is controlled by so many parameters; these parameters are effect of shaping, drying, firing process, effect of duration of firing, and effect of cooling. In this study these parameters are controlled with process defined in practical part, so practically found $0.5 \%$ specified electrolyte solution given a highly compression strength values for porcelain body firing at $1350^{\circ} \mathrm{C}$. From fig. (5) one can find the effect of firing temperature on compression strength, in wide range of 
electrolyte solution as the firing temperature increase, the compression strength increase because of liquid phase effect.

\section{Conclusions}

The conclusions behind this study are:

1. $2 \%$ adding $\mathrm{ZnO}$ mineralized improved The dielectrics, thermal and mechanical properties. with electrolyte solution of concentration of $0.2 \%$ under sintering temperature $\left(1350{ }^{\circ} \mathrm{C}\right)$.

2. $(0.2 \%)$ concentration of electrolyte solution is optimized value in electrical insulator body prepare by using Iraqi clay on raw materials.

\section{References}

[1] Rex, W. Grimshaw. "The Chemistry and Physical of Clays and Allied Ceramic Materials" ${ }^{\text {th }}$ by Rex, W. Grimshaw (1971).

[2] Charles, M. L. "Engineering Materials Hand book", $1^{\text {st }}$ edition, by a staff of specialists (1958).

[3] Sondi, I. \& Pravdi, V. Croatica Chemical Acta, CCACAA 71 (4) 1061 1074 (1998).

[4] Jianzhoug, Wu. And Huagao, G. "Journal of Chemical Physics"vol.120, No.15, (2004).

[5] Grim, R. "Applied Clay Mineralogy" McGraw-Hill book company, Inc. New York and London (1962).

[6] Frank, m. c. "Insulating Materials for Design and Engineering Practice" John Wiely \&Sons,Inc. New York, (1962).

[7] ASTM Designation D150 - 68. "Standard Methods for Test A.C Loss Characteristics and Dielectric Constant (Permittivity) of Solid Electrical Insulating Material".

[8] Harrop, P. J. "Dielectrics" Butter worth and Co. (publishers) Ltd. London, (1972).

[9] Kingery,W. D. "Introduction to Ceramics", John wiely, New York, (1976).

[10] Smylh, Ch. Ph. "Dielectric Behavior and Structure" Mc Graw-Hill book Company, Inc. New York, (1955).

[11] Callister, W. D. "Material Science and Engineering An Introduction", $5^{\text {th }}$ edition, by John Wielly \& Sons(2000).
[12] Askeland, D. R. "The Science and Engineering of Materials", Van nostrand Reinhold international Co. Ltd, Hong Kong (1988).

[13] Mangonon, P. L. "The Principles of Materials Science and Engineering Design" by Prentice-Hall, Inc. New Jersey (1999).

[14] Skoog, D. A. and West, D.M. "Analytical Chemistry and Introduction" $4^{\text {th }}$ edition, by CBS College publishing, Chicago, (1986).

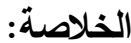

أجرى البحث لتحضير جسم بور سلين ي يمكن

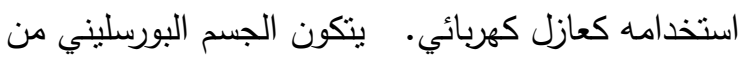

كاؤلين دويخله،رمل زجاج أرضمه، فلدسبار وبنسب وزنيه

(45 \%, 30\% , 25\%) على التوالي. وأجريت معامله

كيميائية لكل من الكاؤلين و السليكا بهذف تتقيتها من

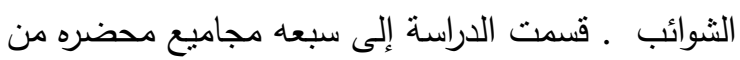

هذه المواد طبقا لنسب المضافة من المحلول الاككتروليتي

الذي يحتوي على (2:1) أما

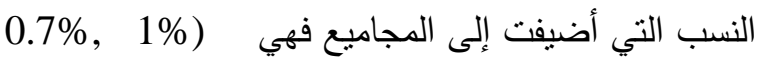

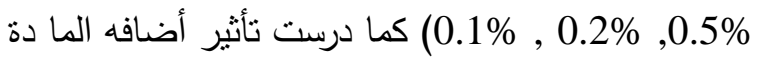
المعد نة ZnO بنسبه (0.2\%). تم قياس خواص العزل الكهربائي (ثابت العزل و معامل الفقدان العزلي) للنماذج بند المكبوسة بعد مراحل التجفيف والتلبيد لدرجات حرارة مختلفة ( كما نم قياس الخواص الفيزيائية لهذه النماذج التي تشمل التوصليه الحرارية بعد ذلك أجريت القياسات الميكانيكية المتضمنة قابليه الانضغاط.

أظهرت نتائج القياسات أنه بالإمكان نشكيل عوازل

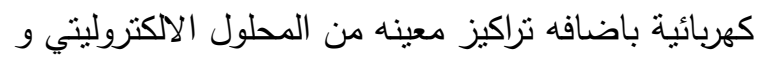

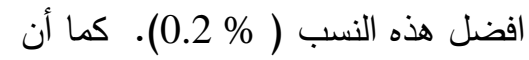

أضافه

العزل الكهربائي للمادة ـوأن دراسة الخواص الحرارية

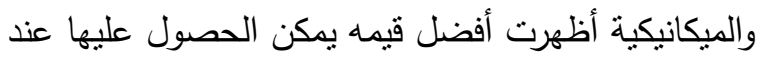
التراكيز (0.2\% - $0.5 \%$ ) للدحلول الالكتروليتي عند درجه حراة 